\title{
Impact of Stale Seedbed Production on Seedling Diseases in Cotton
}

\author{
P. D. Colyer and P. R. Vernon, LSU Agricultural Center, Red River Research Station, Bossier City, LA
}

\begin{abstract}
Colyer, P. D., and Vernon, P. R. 2005. Impact of stale seedbed production on seedling diseases in cotton. Plant Dis. 89:744-748.

Cotton production using conservation tillage practices has increased in the past decade. Most studies involving reduced tillage have shown a reduction in plant populations, which has been attributed to seedling diseases. Although most of these studies have focused on no-till production, cotton planted in the mid-south is often planted using stale seedbeds. The objective of this research was to compare the effect of stale seedbed production and conventional tillage with and without in-furrow fungicides on the incidence and severity of seedling diseases. Tillage systems were established in the fall to focus on the effect of tillage on inoculum density and distribution and to minimize differences in the soil environment between tillage treatments. From 1998 to 2001, cotton was planted and seedling disease was evaluated by counting surviving plant populations, estimating stand uniformity, and conducting root and hypocotyl disease indices. Soil populations of Pythium spp. and Rhizoctonia spp. were also estimated. Plant populations were significantly different between tillage treatments in 1998 and between in-furrow treatments in 2000 . Skip variables were not different in any year. Soil populations of Rhizoctonia spp. were highly variable and not significantly different among treatments in any year. Populations of Pythium spp. were higher in stale seedbed plots in 2000 and 2001. There were no differences in seed cotton yield in any year. In this study, stale seedbed production increased the incidence and severity of seedling diseases of cotton in only one of four years, but the disease was effectively managed with the application of in-furrow fungicides. These results indicate that the potential for an increase in seedling diseases associated with stale seedbed production is minimal and is not sufficient to overlook the potential benefits of this tillage system.
\end{abstract}

Additional keywords: Rhizoctonia solani

Cotton has traditionally been produced using extensive tillage operations that include disking prior to forming beds. Forming the beds often involved the use of an implement (ripper/hipper) that subsoiled (ripper) and formed beds (hipper) in the same operation. In recent years, there has been an increase in reduced tillage practices for cotton production. Conservation tillage is defined as any tillage and planting system that retains greater than $30 \%$ of crop residue on the soil surface after planting (12). There are many different approaches to conservation tillage that include no-till, mulch till, strip till, ridge till, and stale seedbed planting (25). The benefits of conservation tillage include reductions in soil erosion and in labor and energy inputs for production.

Although the benefits of reduced tillage are obvious, these practices have an impact on the physical and biological characteris-

Corresponding author: P. D. Colyer

E-mail: pcolyer@agctr.lsu.edu

Approved for publication by the Director of the Louisiana Agricultural Experiment Station as manuscript \# 04-60-0693.

Accepted for publication 11 March 2005.

DOI: 10.1094/PD-89-0744

(C) 2005 The American Phytopathological Society tics of the soil that may directly or indirectly influence the development of plant diseases $(5,6,16,19,30)$. In some crops, reduced tillage resulted in an increase in foliar diseases $(4,15,26,29)$ and in root and lower stem diseases $(31,34,35)$.

Seedling diseases in cotton are caused by Rhizoctonia solani, Pythium spp., Fusarium spp., and in some areas Thielaviopsis basicola, and these pathogens continue to cause significant disease losses (13). Several studies involving reduced tillage production in cotton have observed reductions in plant population, which have been attributed to seedling diseases $(2,8,11,28,33)$. Most of these studies with cotton involved no-till practices and the use of winter cover crops.

One popular form of reduced tillage on clay soils in the mid-south is stale seedbed production. Under this system, the beds are formed in the fall over the old beds without disking and left idle until spring. When the new beds are formed, cotton stalks and other residue from the previous crop are concentrated in the bed and often are visible on top of the old bed. A cover crop may or may not be planted. The advantages of stale seedbeds are that they allow producers to reduce the number of field operations in the spring, which permits larger areas of land to be planted in less time and does not delay planting while preparing the beds. The role of this debris in the estab- lished bed on the development of seedling diseases in the subsequent crop is not known.

The objective of this research was to compare the effects of stale seedbed production and conventional tillage with and without in-furrow fungicides on the incidence and severity of seedling diseases. Populations of Rhizoctonia spp. and Pythium spp. were also determined in each tillage treatment. Since tillage affects the density and distribution of inoculum and soil environmental factors, all tillage operations were conducted in the fall to minimize differences in the soil environment between tillage treatments. Minimizing soil environmental effects and the application of in-furrow fungicides assisted in discerning the impact of tillage on inoculum density and concentration.

\section{MATERIALS AND METHODS}

Experimental design and plot maintenance. Experiments were conducted on a Moreland clay soil located at the Red River Research Station in Bossier City, LA, from 1998 to 2001. Tests were arranged in a randomized complete block with a split-plot design of treatments with four replications. Main plots were tillage practices and split plots were with or without an in-furrow fungicide treatment. Main plots consisted of 16 rows that were 1.01 $\mathrm{m}$ wide and $135.7 \mathrm{~m}$ long. Split plots were eight rows by $135.7 \mathrm{~m}$. The two tillage practices evaluated were reduced tillage (stale seedbed) and conventional tillage. To reduce any delays in planting and reduce the effects of tillage on soil temperature and moisture in the spring, all tillage operations were conducted in the fall. For the reduced tillage operation, beds were formed in the fall after harvest and stalk shredding without any disking. Under conventional tillage, the field was disked prior to forming beds. All treatments were fallow in the winter and maintained in the same plots in each of the 4 years of the experiment. Plots were sprayed with paraquat dichloride (Gramoxone Extra, Zeneca Ag Products, Wilmington, DE) approximately 2 weeks prior to planting to kill winter annuals. The in-furrow fungicide treatment was PCNB + etridiazole at $7.28 \mathrm{~kg} / \mathrm{ha}$ (Terraclor Super X 18.8G, Crompton Co., Middlebury, CT).

Cotton was planted on 17, 17, 19, and 20 April in 1998, 1999, 2000, and 2001, respectively. Cotton cultivars were Paymaster 1220 BG/RR in 1998 and Deltapine 451B/RR (Delta Pine and Land Co., Scott, MS) in 1999 through 2001. All cotton seed 
were commercially treated with triadimenol, thiram, and metalaxyl (RTUBaytan-Thiram and Apron FL, Gustafson Inc., Plano, TX). All plots were treated with aldicarb at $3.7 \mathrm{~kg} / \mathrm{ha}$ (Temik $15 \mathrm{G}$, Bayer CropScience, Research Triangle Park, NC) to control nematodes and early season insects. Plots were side-dressed with $32 \%$ liquid $\mathrm{N}$ at 67.7 to $78.4 \mathrm{~kg} \mathrm{~N} / \mathrm{ha}$ approximately 4 to 6 weeks after planting. Weeds and insects were controlled according to Louisiana Cooperative Extension Service guidelines. Yield was determined by harvesting the two center rows of each plot with a mechanical harvester.

Disease incidence and severity. Seedling disease was assessed by counting surviving plant populations and rating the roots and hypocotyls of surviving plants. Plant populations were counted from a 30.5-m section from the fourth or fifth row in each plot at approximately 21 and 42 days after planting (DAP). At 42 DAP, stand uniformity was estimated by counting the number of skips and determining the average length per skip. A skip is defined as a distance greater than $30.5 \mathrm{~cm}$ between seedlings. A skip index was calculated by assigning a value of 1 for every 30.5 -cm skip and adding one for every 15 $\mathrm{cm}$ greater than $30.5 \mathrm{~cm}$ (10). Root and hypocotyl disease indices were determined by arbitrarily removing 10 plants from each plot and estimating the extent of root and hypocotyl necrosis. The root disease severity index was based on a scale of 1 to 6 , where $1=$ no root discoloration, $2=1$ to $19 \%, 3=20$ to $40 \%, 4=41$ to $60 \%, 5=$ 61 to $80 \%$, and $6=>80 \%$ of the root system discolored. The hypocotyl disease severity index was based on a scale of 1 to 3 , where $1=$ no symptoms, $2=$ nongirdling lesion, and $3=$ girdling lesion.
Fungal populations. Soil samples were collected from each tillage plot prior to planting to a depth of $20 \mathrm{~cm}$ using a 2.5cm-diameter sampling tube. Approximately 25 soil cores per plot were arbitrarily collected from the center of the planting bed from the two center rows. Soil samples were refrigerated at 2 to $5^{\circ} \mathrm{C}$ and assayed within 3 weeks of collection, except in 1999. In 1999, the soil samples were refrigerated for 6 weeks before assaying. Populations of Pythium spp. were quantified by dilution plating on $\mathrm{P}_{5} \mathrm{ARP}$ medium (24). Twenty-five grams of soil were suspended in $250 \mathrm{ml}$ of $0.2 \%$ water agar and shaken on an orbital shaker for 20 to $30 \mathrm{~min}$ prior to dilution plating.

Rhizoctonia spp. populations were determined using a beet seed assay (27). Fifty autoclaved red beet seeds were mixed with $100 \mathrm{~g}$ of soil in a 9-cm petri dish and incubated for $48 \mathrm{~h}$. The seed were recovered on a 1.41-mm screen, washed under running water, and placed on $2 \%$ water agar. After 24 to $36 \mathrm{~h}$, hyphal tips were transferred to potato carrot agar acidified with 50\% lactic acid (PCAL) and identified. Starting in 1999, isolates identified as Rhizoctonia species were stained to determine the nuclear condition (1), and the anastomosis group (AG) of the $R$. solani isolates was determined by pairing isolates with known tester isolates on cellophane (9).

Environmental data. From 1998 to 2001, soil temperature was measured using an Onset Hobo soil temperature probe programmed to record soil temperature every $30 \mathrm{~min}$. The probes were buried at $10 \mathrm{~cm}$ in the row in a stale seedbed plot. Rainfall data were recorded at a weather station less than $500 \mathrm{~m}$ from the field.

Statistical analysis. Since cotton seedling diseases are influenced by soil tem- perature and moisture, and these parameters were highly variable among years, the data were analyzed by year. All experimental data were analyzed using analysis of variance for split plots using the general linear model (GLM) procedures of SAS (SAS Institute, Cary, NC). The hypocotyl disease index was square root transformed $(\sqrt{ }(X+0.05))$ prior to analysis. The root disease index was converted to the midpoint of the percentage range for each rating prior to analysis. Only main effects (tillage and fungicide application) means are presented in data tables, unless there was a significant interaction for any year.

\section{RESULTS}

Disease incidence and severity. There was a trend toward higher plant populations in the conventional tillage plots than in the stale seedbed plots in most years, but only in 1998 were plant populations at 21 and 42 DAP significantly higher with conventional tillage (Table 1). There were no significant differences in plant populations between tillage and in-furrow treatments in 1999 and 2001. The interaction between fungicide application and tillage was significant in 2000. Fungicides improved plant populations in the stale seedbed plots, but there was no difference between fungicide treatments in the conventional tillage plots.

None of the skip parameters were significantly different in any year (Table 2). Since plant populations were significantly different among tillage treatments in 1999, it would be expected that some or all of the skip parameters might be different, but skip index, average skip length, and number of skips were insignificant at $P=0.08$, 0.07 , and 0.07 , respectively.

Table 1. Effect of tillage and in-furrow fungicide application on plant populations at 21 and 42 days after planting (DAP)

\begin{tabular}{|c|c|c|c|c|c|c|}
\hline \multirow[b]{3}{*}{ Tillage $^{x}$} & \multicolumn{6}{|c|}{ Plant populationw } \\
\hline & \multicolumn{3}{|c|}{21 DAP } & \multicolumn{3}{|c|}{42 DAP } \\
\hline & With fungicide ${ }^{y}$ & Without fungicide & Mean $^{z}$ & With fungicide & Without fungicide & Mean \\
\hline \multicolumn{7}{|l|}{1998} \\
\hline Conventional & 220 & 211 & $215 *$ & 188 & 188 & $188 *$ \\
\hline Stale seedbed & 178 & 175 & $177 *$ & 144 & 143 & $144 *$ \\
\hline Mean & 199 & 193 & & 166 & 166 & \\
\hline \multicolumn{7}{|l|}{1999} \\
\hline Conventional & 201 & 197 & 199 & 200 & 195 & 198 \\
\hline Stale seedbed & 212 & 198 & 204 & 211 & 198 & 205 \\
\hline Mean & 206 & 197 & & 207 & 197 & \\
\hline \multicolumn{7}{|l|}{2000} \\
\hline Conventional & 316 & 320 & 318 & 322 & 325 & 323 \\
\hline Stale seedbed & $311^{*}$ & $277 *$ & 294 & $325 *$ & $285 *$ & 305 \\
\hline Mean & 314 & 299 & & 323 & 305 & \\
\hline \multicolumn{7}{|l|}{2001} \\
\hline Conventional & 303 & 302 & 303 & 281 & 295 & 288 \\
\hline Stale seedbed & 281 & 297 & 289 & 256 & 277 & 267 \\
\hline Mean & 292 & 300 & & 269 & 286 & \\
\hline
\end{tabular}

w Plants per $30.5 \mathrm{~m}$.

${ }^{\mathrm{x}}$ Conventional $=$ plots are disked before forming beds; stale seedbed $=$ plots are not disked before forming beds.

${ }^{\mathrm{y}}$ The fungicide was PCNB plus etridiazole (Terraclor Super X 18.8G) applied at $7.28 \mathrm{~kg} / \mathrm{ha}$.

${ }^{\mathrm{z}}$ Means down a column or across a row within a year designated with an asterisk indicate that tillage or fungicide effect was significantly different $(P \leq$ 0.05). Interaction between fungicide and tillage was significant in 2000 . 
Disease indices were significantly different between in-furrow fungicide treatments only in 1999 (Table 3). The application of in-furrow fungicide lowered both root and hypocotyl ratings. Tillage had no effect on disease indices in any year.

Fungal populations. Soil populations of Pythium spp. at planting were significantly different among tillage treatments in 2000 and 2001 (Table 4). In both years, populations were higher in the stale seedbed plots than in the conventionally tilled plots. Overall soil populations were lower

Table 2. Effect of tillage and in-furrow fungicide application on mean skip index, average skip length, and number of skips

\begin{tabular}{|c|c|c|c|c|}
\hline & 1998 & 1999 & 2000 & 2001 \\
\hline \multicolumn{5}{|l|}{ Skip index ${ }^{v}$} \\
\hline \multicolumn{5}{|l|}{ Tillage $^{w}$} \\
\hline Conventional & 27.4 & 24.8 & 7.5 & 16.0 \\
\hline Stale seedbed & 48.8 & 24.0 & 8.8 & 17.5 \\
\hline \multicolumn{5}{|l|}{ Fungicide $^{\mathrm{x}}$} \\
\hline With & 38.3 & 26.5 & 7.5 & 19.9 \\
\hline Without & 37.9 & 22.4 & 8.8 & 13.6 \\
\hline \multicolumn{5}{|l|}{ Skip length $(\mathrm{cm})^{\mathrm{y}}$} \\
\hline \multicolumn{5}{|l|}{ Tillage } \\
\hline Conventional & 43.2 & 39.9 & 38.9 & 49.5 \\
\hline Stale seedbed & 52.3 & 40.6 & 35.5 & 42.7 \\
\hline \multicolumn{5}{|l|}{ Fungicide } \\
\hline With & 47.0 & 40.6 & 34.0 & 48.2 \\
\hline Without & 48.5 & 39.9 & 39.9 & 43.9 \\
\hline \multicolumn{5}{|l|}{ Number of skips $\mathrm{z}$} \\
\hline \multicolumn{5}{|l|}{ Tillage } \\
\hline Conventional & 19.3 & 19.8 & 6.4 & 10.0 \\
\hline Stale seedbed & 24.9 & 18.8 & 6.5 & 11.3 \\
\hline \multicolumn{5}{|l|}{ Fungicide } \\
\hline With & 22.8 & 21.4 & 6.3 & 11.6 \\
\hline Without & 21.4 & 17.1 & 6.6 & 9.6 \\
\hline
\end{tabular}

${ }^{\mathrm{v}}$ Mean sum of skip indices within a plot where $0=$ no skips greater than $30.5 \mathrm{~cm}, 1=$ skip 30.5 to $45.7 \mathrm{~cm}$ in length, and 1 for each additional $15.2 \mathrm{~cm}$ per skip. Means of tillage and fungicide treatments were not significantly different $(P \leq 0.05)$ in any year.

${ }^{\mathrm{w}}$ Conventional $=$ plots are disked before forming beds; stale seedbed $=$ plots are not disked before forming beds.

${ }^{x}$ The fungicide was PCNB plus etridiazole (Terraclor Super X 18.8G ) applied at $7.28 \mathrm{~kg} / \mathrm{ha}$.

${ }^{y}$ Average length $(\mathrm{cm})$ of all skips within a plot. Means of tillage and fungicide treatments were not significantly different $(P \leq 0.05)$ in any year.

${ }^{\mathrm{z}}$ Total number of skips per plot. A skip is defined as a distance of $30.5 \mathrm{~cm}$ or greater between plants. Means of tillage and fungicide treatments were not significantly different $(P \leq 0.05)$ in any year.

Table 3. Effect of tillage and in-furrow fungicide application on root and hypocotyl disease indices

\begin{tabular}{|c|c|c|c|c|}
\hline & 1998 & 1999 & 2000 & 2001 \\
\hline \multicolumn{5}{|c|}{ Hypocotyl disease index ${ }^{w}$} \\
\hline \multicolumn{5}{|c|}{ Tillage $^{\mathrm{x}}$} \\
\hline Conventional & 2.3 & 1.5 & 2.1 & 2.0 \\
\hline Stale seedbed & 2.3 & 1.6 & 1.8 & 1.9 \\
\hline \multicolumn{5}{|l|}{ Fungicide $^{y}$} \\
\hline With & 2.3 & $1.4 *$ & 1.9 & 2.0 \\
\hline Without & 2.2 & $1.7 *$ & 2.0 & 1.9 \\
\hline \multicolumn{5}{|c|}{ Root disease index ${ }^{z}$} \\
\hline \multicolumn{5}{|c|}{ Tillage } \\
\hline Conventional & 3.1 & 2.6 & 3.2 & 2.7 \\
\hline Stale seedbed & 3.1 & 2.9 & 2.8 & 2.9 \\
\hline \multicolumn{5}{|l|}{ Fungicide } \\
\hline With & 3.2 & $2.4 *$ & 2.8 & 2.8 \\
\hline Without & 3.1 & $3.1 *$ & 3.2 & 2.8 \\
\hline
\end{tabular}

${ }^{\mathrm{w}}$ Hypocotyl disease index on a scale of 1 to 3 , where $1=$ no visible lesions, $2=$ nongirdling lesions, and 3 = girdling lesion. Means down a column designated with an asterisk indicate that tillage or fungicide effect was significantly different $(P \leq 0.05)$. Actual index values are shown, but the means were square root transformed $(\sqrt{ } X+0.5)$ prior to analysis.

${ }^{\mathrm{x}}$ Conventional $=$ plots are disked before forming beds; stale $=$ plots are not disked before forming beds.

y The fungicide was PCNB plus etridiazole (Terraclor Super X 18.8G) applied at $7.28 \mathrm{~kg} / \mathrm{ha}$.

${ }^{\mathrm{z}}$ Root disease index on a scale of 1 to 6 , where $1=$ no damaged roots, and $6=$ between 80 and $100 \%$ of the roots damaged. Means down a column designated with an asterisk indicate that tillage or fungicide effect was significantly different $(P \leq 0.05)$. Actual means are shown, but index values were converted to the midpoint of the percentage range for each rating prior to analysis. in 1999 than in the other years. Soil samples in 1999 were stored for a longer period and may have resulted in a reduction in populations.

Populations of Rhizoctonia spp. were highly variable among plots, and there were no significant differences between tillage treatments. Fifty percent of the isolates were binucleate Rhizoctonia species. Most of the $R$. solani isolates were AG4, but there were four AG7 isolates. Two were recovered from a conventional tillage plot in 1999, and one each was recovered from a conventional tillage plot and a stale seedbed plot in 2000 .

Seed cotton yield. There were no differences in yield between tillage treatments or between in-furrow treatments in any of the years (Table 5). There was an interaction between tillage and in-furrow application in 1999. For both stale seedbed and conventional tillage, yields were significantly different between application and no application of an in-furrow fungicide. Seed cotton yields were very low in 1998, presumably due to drought conditions. In 1998, from 1 June to 1 August, total rainfall was only $70.4 \mathrm{~mm}$, and average air temperatures were 36.2 and $38.3^{\circ} \mathrm{C}$ in June and July, respectively.

\section{DISCUSSION}

Prior research has indicated that tillage affects diseases by either influencing physical properties of the soil, or through the survival of pathogens in plant debris and distribution of plant debris $(5,30,32)$. Tillage operations for both tillage regimes were conducted in the fall to limit the differences in soil temperature, moisture, and other physical soil properties that might occur with spring versus fall soil disturbance. Under stale seedbed production, cotton debris is concentrated in the seed bed, while under conventional tillage disking tends to spread the debris over the entire plot area. The results of other research on the effects of reduced tillage on cotton seedling diseases have been variable, but most have reported a reduction in plant populations. In a 10-year study in Tennessee, plant populations were often reduced in no-till plots and often improved by the application of in-furrow fungicide at planting (11). In Alabama, plant populations were lower in conservation tillage plots than in conventional tillage, and in plots planted to a legume winter cover crop than in fallow soils (28). Batson and $\mathrm{Ca}-$ ceres (2) did not observe any differences in plant populations between stale seedbed and conventional productions systems. In a cotton-triticale double-cropping system over a 4- or 5-year period, cotton populations were reduced in the no-till plots compared with moldboard plowing (33).

Providing conditions for rapid seed germination and seedling emergence are often recommended for the management of seedling diseases. This includes delaying 
planting until average soil temperatures are at least $18^{\circ} \mathrm{C}(14)$. In every year of this study, there were several days during the first 2 weeks after planting in which soil temperatures were below $18^{\circ} \mathrm{C}$ (Fig. 1). These conditions should have slowed seed germination and seedling emergence, and provided sufficient levels of seedling disease in the test for evaluation of treatment effects.

In this study, only in 1998 was tillage a significant factor on plant populations. Since there was no significant difference between no fungicide and in-furrow fungicide application this year, some factor other than seedling disease may have been responsible for the stand failure. With reduced tillage, others have observed an increase in cutworms $(18,23)$ and poor seed bed preparation that results in reduced seed contact with the soil (23), which reduced stands. Although attempts were made in this study to control early season insects, rainfall after seedling emergence in 1998 delayed the application of insecticides to control cutworms. Extensive cutworm damage was observed in the plots, which most likely contributed to reduced plant populations.

In 2000, plant populations at 14 and 42 DAP were not different between in-furrow treatments in the conventional tillage, but were improved with a fungicide application in the stale seedbed plots. Nearly 250 $\mathrm{mm}$ of rainfall during the first 21 days after planting in 2000 resulted in extremely wet conditions. These wet soils and cool soil temperatures (Fig. 1) are conducive to seedling infection by Pythium spp. $(21,22)$. Populations of Pythium spp. in the soil were significantly higher in the stale seedbed plots in 2000, and probably contributed to the increase in seedling disease in these plots. Populations were also higher in 2001 in the stale seedbed plots, but only $19 \mathrm{~mm}$ of rainfall occurred the first 21 days after planting.

None of the skip indices were significantly different, even in 1998 when tillage effects were significant and in 2000 when fungicide effects were significant. In 1998, all three skip indices were nearly significant. The lack of significance is most likely related to the high coefficient of variation (27.4 for the index; 36.3 for average length; 19.9 for number of skips) among the plots. In 2000, surviving plant populations exceeded nine plants per meter. At this high density of plants, skips longer than $30.5 \mathrm{~cm}$ are uncommon.

Seed cotton yield was not affected by infurrow fungicide application or tillage treatment in any year, although plant populations were significantly different between tillage treatments in 1998 and between in-furrow treatments in 2000. Other researchers have failed to observe yield differences over a range of plant populations $(3,7,17)$. The failure to observe yield differences despite differences in plant
Table 4. Effect of tillage practices on soil populations of Pythium spp. and Rhizoctonia spp. at planting

\begin{tabular}{lcccc}
\hline Tillage & $\mathbf{1 9 9 8}$ & $\mathbf{1 9 9 9}$ & $\mathbf{2 0 0 0}$ & $\mathbf{2 0 0 1}$ \\
\hline Pythium spp. (propagules/g soil)y & & & & \\
Conventional & $583 \mathrm{a}$ & $89 \mathrm{a}$ & $497 \mathrm{a}$ & $452 \mathrm{a}$ \\
Stale seedbed & $628 \mathrm{a}$ & $90 \mathrm{a}$ & $557 \mathrm{~b}$ & $876 \mathrm{~b}$ \\
Rhizoctonia spp. $^{\mathrm{z}}$ & & & & \\
Conventional $^{\text {Stale seedbed }}$ & - & $6.3 \mathrm{a}$ & $4.3 \mathrm{a}$ & $1.5 \mathrm{a}$ \\
\hline
\end{tabular}

${ }^{\mathrm{y}}$ Means followed by the same letter within a year are not significantly different according to ANOVA $(P \leq 0.05)$. Data based on the mean of five dilution plates for each replication. There were four replications.

${ }^{\mathrm{z}}$ Means followed by the same letter within a year are not significantly different according to ANOVA $(P \leq 0.05)$. Based on the number of 50 beet seeds mixed with $100 \mathrm{~g}$ of soil that were colonized. Data were not collected in 1998 .

Table 5. Effect of tillage and in-furrow fungicide application on seed cotton yield

\begin{tabular}{|c|c|c|c|}
\hline \multirow[b]{2}{*}{ Tillage $^{y}$} & \multicolumn{3}{|c|}{ Seed cotton $(\mathrm{kg} / \mathrm{ha})^{\mathrm{x}}$} \\
\hline & With fungicide ${ }^{\mathrm{z}}$ & Without fungicide & Mean \\
\hline \multicolumn{4}{|l|}{1998} \\
\hline Conventional & 710 & 771 & 740 \\
\hline Stale seedbed & 750 & 720 & 735 \\
\hline Mean & 730 & 745 & \\
\hline \multicolumn{4}{|l|}{1999} \\
\hline Conventional & $2,069 *$ & $1,962 *$ & 2,015 \\
\hline Stale seedbed & $1,962 *$ & $2,071 *$ & 2,016 \\
\hline Mean & 2,015 & 2,016 & \\
\hline \multicolumn{4}{|l|}{2000} \\
\hline Conventional & 1,719 & 1,719 & 1,719 \\
\hline Stale seedbed & 1,842 & 1,847 & 1,845 \\
\hline Mean & 1,781 & 1,783 & \\
\hline \multicolumn{4}{|l|}{2001} \\
\hline Conventional & 1,519 & 1,513 & 1,517 \\
\hline Stale seedbed & 1,391 & 1,556 & 1,473 \\
\hline Mean & 1,455 & 1,538 & \\
\hline
\end{tabular}

${ }^{\mathrm{x}}$ Tillage and fungicide effects were not significant in any year. There was a significant interaction in 1999. For both stale seedbed and conventional tillage, yields were significantly different between application and no application of an in-furrow fungicide.

${ }^{\mathrm{y}}$ Conventional $=$ plots are disked before forming beds; stale $=$ plots are not disked before forming beds.

${ }^{\mathrm{z}}$ Fungicide was PCNB plus etridiazole (Terraclor Super X 18.8G) applied at $7.28 \mathrm{~kg} / \mathrm{ha}$.

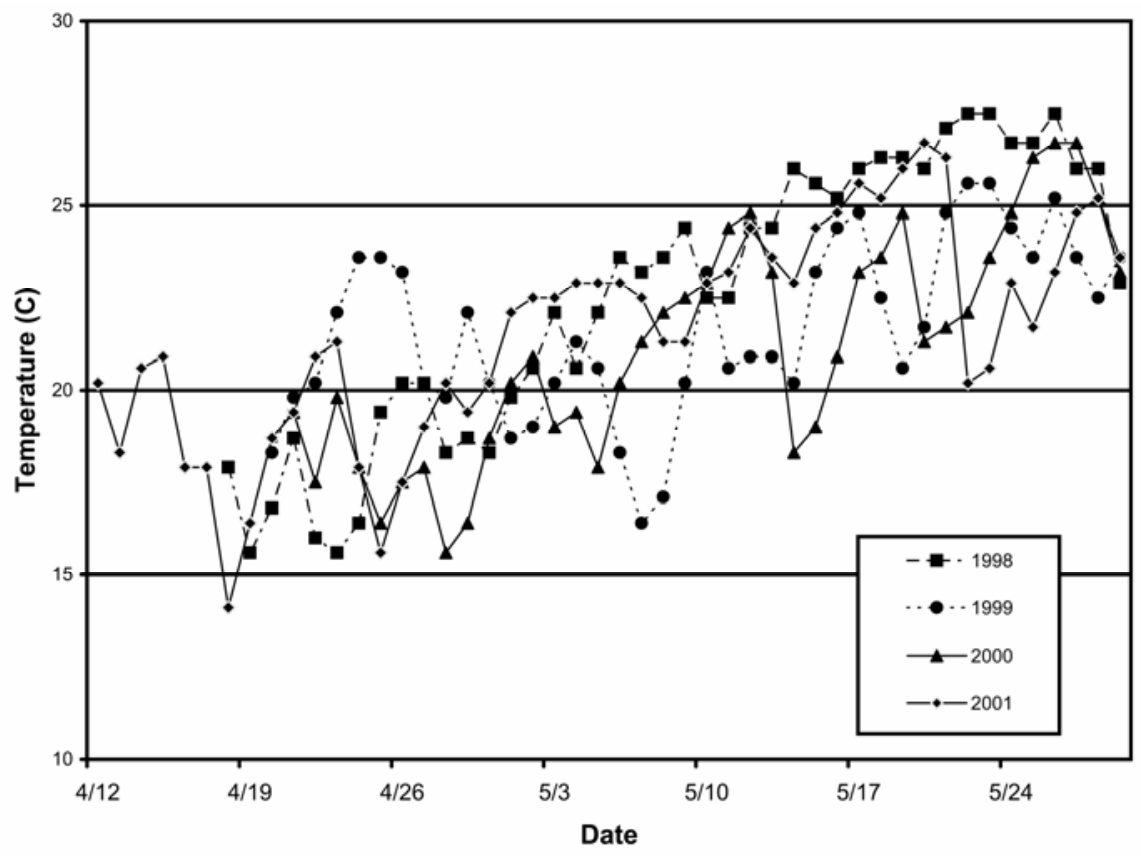

Fig. 1. Soil temperature at $10 \mathrm{~cm}$ from 1998 to 2001 for the first 30 days after planting. 
populations is most likely related to the ability of the cotton plant to adapt its shape to compensate for reduced plant populations $(17,20)$. Plants at lower populations have more mainstem nodes and monopodial branches $(3,17)$ and greater fruit retention (3) and larger bolls $(3,7)$. These components all contribute to yield and allow the plant to compensate for reduced plant populations.

In this study, plant populations were reduced by stale seedbed production in only one of four years. Since fungicides did not result in higher populations, the reduced plant populations were most likely associated with greater cutworm damage. In one year, the application of an in-furrow fungicide improved plant populations in the stale seedbed plots, but not the conventionally tilled plots. This demonstrates the potential for greater seedling disease in stale seedbed production, but it also demonstrates ability to manage seedling diseases with fungicide applications. Bockus and Shroyer (5) discuss the significance of fungicides to control diseases in reduced tillage production systems. Based on these results, stale seedbed production does not appear to present a significantly greater potential for the development of seedling diseases.

Previous studies frequently observed a stand response associated with no or reduced tillage $(2,8,11)$. Although the response was attributed to pathogens, the means by which this response occurred was not always determined. The decrease in stand could be due to an increase in pathogen populations or concentration of pathogen inoculum in the row, which would warrant changes in tillage practices or in fungicide recommendations. Data from this study do not support an increase in pathogen populations or the concentration of inoculum in the row. The other reason for a reduction in plant populations associated with no or reduced tillage would be a change in soil environment. In this study, differences in the soil environment between tillage treatments were minimized by establishing the beds for all treatments in the fall. The lack of tillage response in this study compared with the other studies cited would indicate that changes in the soil environment were more important to stand establishment than inoculum levels. No or reduced tillage would increase the incidence and severity of seedling diseases and reduce plant stands by creating cooler or wetter soil environment for the same planting date. If environment is the critical factor in determining the incidence of cotton seedling diseases in conservation tillage systems, the impact of tillage on seedling diseases could be diminished by changing the decision to plant from a calendar-based decision to one based on soil temperature.

\section{LITERATURE CITED}

1. Bandoni, R. J. 1974. Safranin-0 as a rapid nuclear stain for fungi. Mycologia 63:873-874.

2. Batson, W. E., Jr., and Caceres, J. 2000. Evaluation of seedling disease control strategies for cotton planted in conventional and stale bed tillage systems. Pages 145-146 in: Proc. Beltwide Cotton Prod. Conf., Natl. Cotton Counc., Memphis, TN.

3. Bednarz, C. W., Bridges, D. C., and Brown, S. M. 2000. Analysis of cotton yield stability across population densities. Agron. J. 92:128135.

4. Bockus, W. W., O'Connor, J. P., and Raymond, P. J. 1983. Effect of residue management method on incidence of Cephalosporium stripe under continuous winter wheat production. Plant Dis. 67:1323-1324.

5. Bockus, W. W., and Shroyer, J. P. 1998. The impact of reduced tillage on soilborne plant pathogens. Annu. Rev. Phytopathol. 36:485500 .

6. Boosalis, M. G., and Doupnik, B., Jr. 1976. Management of crop disease in reduced tillage systems. Bull. Entomol. Soc. Am. 22:300-302.

7. Bridge, R. R., Meredith, W. R., Jr., and Chism, J. F. 1973. Influence of planting method and plant population on cotton (Gossypium hirsutum L.). Agron. J. 65:104-109.

8. Brown, S. M., Whitwell, T., Touchton, J. T., and Burmester, C. H. 1985. Conservation tillage systems for cotton production. Soil Sci. Soc. Am. J. 49:1256-1260.

9. Carling. D. E., Leiner, R. H., and Kebler, K. M. 1987. Characterization of a new anastomosis group (AG-9) of Rhizoctonia solani. Phytopathology 77:1609-1612.

10. Chambers, A. Y. 1989. Further evaluation of effects of selected skip levels in stands and replanting on cotton yields. Page 40 in: Proc. Beltwide Cotton Prod. Conf., Natl. Cotton Counc., Memphis, TN.

11. Chambers, A. Y. 1995. Conventional tillage vs. conservation tillage and their effects on disease severity. Pages 203-204 in: Proc. Beltwide Cotton Prod. Conf., Natl. Cotton Counc., Memphis, TN.

12. Conservation Technology Information Center (CTIC). 1995. Tillage Systems Definitions. Conservation Impact 13(9).

13. DeVay, J. E. 2001. Seedling diseases. Pages 13-14 in: Compendium of Cotton Diseases. T. L. Kirkpatrick and C. S. Rothrock, ed. American Phytopathology Society, St. Paul, MN.

14. DeVay, J. E., and Rothrock, C. S. 2001. Control of seedling diseases. Pages 19-20 in: Compendium of Cotton Diseases. T. L. Kirkpatrick and C. S. Rothrock, ed. American Phytopathology Society, St. Paul, MN.

15. Dill-Macky, R., and Jones, R. K. 2000. The effect of previous crop residues and tillage on Fusarium head blight of wheat. Plant Dis. 84:71-76.

16. Doran, J. W. 1980. Soil microbial and biochemical changes associated with reduced tillage. Soil Sci. Soc. Am. J. 44:765-771.

17. Fowler, J. L., and Ray, L. L. 1977. Response of two cotton genotypes to five equidistant spac- ing patterns. Agron. J. 69:733-738.

18. Gaylor, M. J. 1989. Direct and indirect effects of conservation tillage on the management of insect pests of cotton. Pages 10-12 in: Proc. Southern Conservation Tillage Conf. Sustainable Agric., 12th. Tallahasee, FL.

19. Gupta, S. C., Larson, W. E., and Linden, D. R. 1983. Tillage and surface residue effects on soil upper boundary temperatures. Soil Sci. Soc. Am. J. 47:1212-1218.

20. Hake, K., Burch, T., Harvey, L., Kerby, T., and Supak, J. 1991. Plant populations. Cotton Physiol. Today: 2(4).

21. Hillocks, R. J. 1992. Seedling diseases. Pages 1-38 in: Cotton Diseases. R. J. Hillocks, ed. CAB Int.; Wallingford, England.

22. Howell, C. R. 2001. Diseases caused by Pythium species. Pages 14-15 in: Compendium of Cotton Diseases. T. L. Kirkpatrick and C. S. Rothrock, ed. American Phytopathological Society, St. Paul, MN

23. Hutchinson, R. L., and Shelton, W. L. 1990. Alternative tillage systems and cover crops for cotton production on the Macon Ridge. Louisiana Agric. 33(4):6-8.

24. Jeffers, S. N., and Martin, S. B. 1986. Comparison of two media selective for Phy tophthora and Pythium species. Phytopathology 70:1038-1043.

25. Keisling, T. 1998. Glossary of commonly used conservation tillage terms. Pages 662 in: Proc. Beltwide Cotton Prod. Conf., Natl. Cotton Counc., Memphis, TN.

26. Ntahimpera, N., Dillard, H. R., Cobb, A. C., and Seem, R. C. 1997. Influence of tillage practices on anthracnose development and distribution in dry bean fields. Plant Dis. 81:7176.

27. Papavizas, G. C., Adams, P. B., Lumsden, R. D., Lewis, J. A., Dow, R. L., Ayers, W. A., and Kantzes, J. G. 1975. Ecology and epidemiology of Rhizoctonia solani in field soil. Phytopathology 65:871-877.

28. Rickerl, D. H., Gordon, W. B., Curl, E. A., and Touchton, J. T. 1988. Winter legume and tillage effects on cotton growth and soil ecology. Soil Tillage Res. 11:63-71.

29. Roane, C. W., Harrison, R. L., and Genter, C. F. 1974. Observations on gray leaf spot of maize in Virginia. Plant Dis. Rep. 38:456-459.

30. Rothrock, C. S. 1992. Tillage systems and plant disease. Soil Sci. 154:308-315.

31. Rovira, A. D. 1986. Influence of crop rotation and tillage on Rhizoctonia bare patch of wheat. Phytopathology 76:669-673.

32. Sumner, D. R., Doupnik, B., Jr., and Boosalis, M. G. 1981. Effects of reduced tillage and multiple cropping on plant diseases. Annu. Rev. Phytopathol. 19:167-187.

33. Sumner, D. R., Dowler, C. C., Johnson, A. W., and Baker, S. H. 1995. Conservation tillage and seedling diseases in cotton and soybean double-cropped with triticale. Plant Dis. 79:372-375.

34. Sumner, D. R., Smittle, D. A., Threadgill, E. D., Johnson, A. W., and Chalfant, R. B. 1986. Interactions of tillage and soil fertility with root diseases in snap bean and lima bean in irrigated multiple-cropping systems. Plant Dis. 70:730-735.

35. Workneh, F., and Yang, X. B. 2000. Prevalence of Sclerotinia stem rot of soybeans in the north-central United States in relation to tillage, climate, and latitudinal positions. Phytopathology 90:1375-1382. 